\title{
Correction to: The relationship between COVID-19 and the dental damage stage determined by radiological examination
}

\author{
Dursun Ali Sirin ${ }^{1}$ (D) Fatih Ozcelik ${ }^{2}$
}

Published online: 3 February 2021

(c) Japanese Society for Oral and Maxillofacial Radiology and Springer Nature Singapore Pte Ltd. 2021

\section{Correction to: Oral Radiology \\ https://doi.org/10.1007/s11282-020-00497-0}

In the original publication of the article, the sub heading that reads as "Dental radiographsmakalenin revize son hali ve hakeme cevap mektubu" should read as "Dental radiographs".

The original article has been corrected.

Publisher's Note Springer Nature remains neutral with regard to jurisdictional claims in published maps and institutional affiliations.

The original article can be found online at https://doi.org/10.1007/ s11282-020-00497-0.

Dursun Ali Sirin

dtalisirin@gmail.com

1 University of Health Sciences, Hamidiye Faculty of Dentistry, Department of Endodontics and Sultan 2. Abdulhamid Han Training Hospital, Saglik Bilimleri Universitesi, 34668 Istanbul, Turkey

2 University of Health Sciences, Sultan Abdülhamid Han Training Hospital, Biochemistry Specialist Department of Medical Biochemistry, Sağlık Bilimleri Üniversitesi, İstanbul, Turkey 